EGU2020-9242

https://doi.org/10.5194/egusphere-egu2020-9242

EGU General Assembly 2020

(c) Author(s) 2021. This work is distributed under

the Creative Commons Attribution 4.0 License.

\title{
Recent patterns of discharge and sediment output of the Gorner Glacier, Switzerland
}

\author{
Günther Prasicek ${ }^{1}$, François Mettra ${ }^{2}$, Stuart Lane ${ }^{2}$, and Frédéric Herman ${ }^{2}$ \\ ${ }^{1}$ University of Lausanne, Interdisciplinary Center for Mountain Research, Bramois, Switzerland \\ ${ }^{2}$ University of Lausanne, Institute of Earth Surface Dynamics, Lausanne, Switzerland
}

Recent climate change is causing rapid retreat of alpine glaciers around the globe. As ice melts and glaciers thin, glacier motion and subglacial processes will change. One of the most relevant aspects for down-valley environments, settlements and infrastructure is the potential change in flow discharge and sediment output.

Here we present the results of an ongoing monitoring program at the Gorner Glacier, Switzerland, the second-largest glacier system in the European Alps. During the melt season of 2018 and 2019, stage and turbidity were monitored with a 5 minute frequency along a turbulent section of the glacial river, located approximately $1 \mathrm{~km}$ downstream of the glacier terminus. For calibration of the turbidity measurements, daily water samples were obtained with an automated pump sampler, supported by additional intermittent manual sampling. The data is complemented by a discharge time series that also contains information on the flushing of a bedload trap at the hydro power weir located about $2 \mathrm{~km}$ downstream of the glacier terminus. The discharge and flushing data have a resolution of 15 minutes. Turbidity and discharge allow estimation of the output of suspended load, while the flushing data inform about bedload. We further measured total organic carbon content of the water samples to infer the water and sediment source.

Data suggest a clear seasonal pattern, not only in discharge and sediment output, but also in suspended sediment concentration (SSC). While SSC is high during snow melt and in early summer, it decreases rapidly in July and stays at similar levels until September. This may indicate exhaustion of sediment storage beneath the glacier, but could also result from a change in subglacial regime, e.g. from a decrease in subglacial water pressure due to the progressive opening of subglacial cavities during the melt season. High fractions of organic carbon, presumably due to lateral sediment input from hillslopes, occur during storms throughout the entire season. 